\title{
Reforming the Compensation Model to Victims of Crime in Indonesia
}

\author{
Hanafi Amrani* \\ Department of Law, Faculty of Law, Universitas Islam Indonesia, 55151, Yogyakarta, \\ Indonesia
}

\begin{abstract}
Indonesia has an obligation to place the protection of human rights against all its citizens, as well as in ensuring compensation for certain victims of crime. Ironically, the conceptual issues such as the inclusion of compensation on the existence of criminals who provide restitution, the unclear technical implementation in the normative legitimacy, as well as the financial problems of the state for compensation show that the compensation for crime victims in Indonesia is still problematic. This study focuses on the ideal idea of reforming the model, form and mechanism for providing compensation to victims of crime in Indonesia. This research uses normative research with secondary data. The approach taken include philosophical, legislation and conceptual, and analyzed descriptively qualitative through literature study. The results of research are; first, the state compensation of crime victims conceptually, juridically and practically has not been able to show the effectiveness of providing compensation for victims of crime; second, reconceptualizing the compensation model through an extra-judicial path, with a material and non-material compensation shape, and using a mechanism that focuses on the involvement of all parties as the concept of restorative justice is an alternative solution to compensation for crime victims in the future.
\end{abstract}

\section{Introduction}

The idea of this research is the compensation concept for victims of crime in order to create an effective fulfillment of the rights of victims of crime that is participatory in Indonesia. The idea is based on three problems of urgency which include; First, compensation is a state obligation that must be fulfilled as a mandate from the constitution to protect human rights [1]. The state philosophically and juridically has an obligation to guarantee the security of every community and provide guarantee of law enforcement when a crime occurs which results in a victim. One form is the guarantee of providing compensation to victims of crime. Ironically, the implementation of compensation is still reaping serious problems due to the compensation model based on court decisions that are legally enforceable [2]. This is considered to be less effective because the court route usually takes a lot of time and often ignores the conditions of the compensation needs. As a consequence, compensation can only

\footnotetext{
*Corresponding author: h.amrani@uii.ac.id
} 
be given if the perpetrator is found guilty and unable to provide restitution to the victims of crime [3]. Thus, if the court cannot prove and list the guilty or compensation is not stated in the verdict, then compensation cannot be given even though it has obviously caused harm to the victims of crime [4].

Second, the form of compensation that has been applied is only material, so that the issue of the state's financial condition in the provision of compensation is always a serious problem. State financial limitations in the provision of compensation for victims of crime [5] have implications for the orientation of consideration for the provision of compensation based solely on financial factors rather than the victims' needs for the losses suffered.

Third, the compensation mechanism is carried out entirely by the judge to decide whether or not a compensation is given to the victim of a crime based on the judge's observation during the trial process [6]. Without adequate regulation regarding compensation in this mechanism, compensation tends to be interpreted subjectively by judges without clear parameters or indicators. This mechanism also seems to severely limit the participation of elements from the perpetrators, victims, and the community (the state) which should be considered in the context of providing ideal compensation for victims of crime.

Based on the three problems above, the need for a practical solution to solve problems related to compensation is the best step to realize the model, form and mechanism for providing compensation to victims of crime in the future. Therefore, this research is aimed to provide solutions to the various problems in providing compensation for victims of certain crimes in the form of concepts, models, forms, and ideal mechanisms for providing compensation to victims of crime in the future.

\section{Methodology}

This research is a normative research. The type of data used is secondary data consisting of primary legal materials, secondary legal materials and tertiary legal materials. The approach method used includes the statute and conceptual approaches. The statute approach is carried out through the review of laws and regulations to analyze and determine the pattern of implementation of compensation by the state. As well as a conceptual approach to address the issue of providing compensation for victims of crime based on relevant concepts and theories. Legal material collection techniques were carried out through literature studies which were analyzed descriptively qualitative.

\section{Dicussion}

\subsection{Implementation of Compensation for Crime Victims in Indonesia}

Nowadays, the development of the fulfillment of reparation rights in Indonesia has undergone a very significant change. Some criminal laws and regulations have detailed the provision of reparations for victims of certain crimes as part of which the state must fulfill [7-8]. Various fulfillment of reparation rights have been arranged in detail in criminal legislation, including compensation for victims of gross violations of human rights and terrorism. Both arrangements for the criminal act again provide an affirmation that the state of Indonesia is very concerned about the existence of the rights of victims of certain crimes, thus, the fulfillment is inherent as a mandate from the constitution [1]. As one of the concrete forms of fulfilling the rights of victims by the state, compensation has been chosen as a place to fulfill state obligations directly to victims of crime. 
Implementation of compensation for crime victims of gross human rights violations and terrorism can be seen from the following analysis; First, regarding the gross violation of human rights. Indonesia regulates the concept of fulfilling compensation for victims of this type of crime in the provisions of the Human Rights Court Act. The term compensation appears in Article 35 paragraph (1) which explains that "every victim of severe human rights violations and/or his heirs can obtain compensation, restitution and rehabilitation". Furthermore, juridically in the explanation of the article, it is explained that what is meant by compensation is compensation given by the state because the perpetrator is unable to provide full compensation which is his responsibility. The explanation confirms that the concept of compensation applied in Indonesia is only in the form of complementary provision of less restitution by perpetrators. The meaning of compensation applied in the law is considered to be contrary to the basic principle of compensation that applies universally. Compensation should be an obligation that must be given by the state to victims of gross human rights violations to make payments in cash or given in various forms, such as mental and physical health care, employment, housing, education and land [9]. In principle, compensation is the state's obligation to victims of gross human rights violations without even having to consider the existence of restitution fulfillment by perpetrators [10]. The regulation directly implies the enforcement of compensation which is only limited if the perpetrator of the crime is found and presented guilty by the judge, so that compensation can be given either in full or only part of the loss suffered by the victim of crime.

On the other hand, the requirement to include compensation in the decision as a consequence of the implementation of compensation by the court made it not absolutely given to the victim even though clearly there had been a loss caused by such gross human rights violations. As in the case of gross human rights violations in Tanjung Priok which did not mention again the decision to provide compensation for victims of appeals and cassation rates that acquitted the perpetrators because they were considered innocent, whereas in the previous decision it was stated that compensation was given to victims who had been harmed [11]. In addition, some other problems that will arise are; first, the period of giving compensation is uncertain and takes a long time to the existence of a binding decision. It was proven that the experience of the human rights court practice that occurred always showed a process that was actually very long for years [11]; second, the concrete amount of compensation that is not yet clear has the potential to provide compensation based solely on the subjectivity of judges and not on the basis of objective indicators of needs due to losses suffered by victims of crime [6].

Second, regarding compensation for victims of terrorism crime. Arrangements regarding compensation given to victims of terrorism are regulated in the Terrorism Act specifically in Article 36 paragraph (1) concerning the scope of compensation in acts of terrorism. This provision explains that the form of compensation includes compensation in the form of material and immaterial. Juridically, the arrangement is considered ideal in understanding the loss of victims which is not only related to material matters, but also losses in other fields is also considered as an effort to fulfill the rights of victims of terrorism. But that does not mean there are no problems, it is because there is no implementing regulation (PP) from the provisions of the Terrorism Act [12] and the lack of regulation coverage that causes obstruction of compensation for victims of terrorism [13]. The blurring of the meaning of compensation in the form of immaterial becomes its own confusion to be implemented, the provision of compensation by the state is carried out through the Minister of Finance based on the decision of the district court [14] as if it illustrates that only losses in the form of financial assistance can be given.

In addition, some problems related to the concept of compensation through the court line in the Terrorism Act include; first, not all victims of terrorism can be accommodated in court decisions because of the limited identification by law enforcement officers in the judicial 
process; second, the provision of compensation is limited to cases where the court has stated that terrorism has occurred and the perpetrator is found guilty; third, the submission of compensation in the court actually does not appear to be participatory towards victims of crime who should also be able to ask for their own rights, as well as for victims who are not included in the identification of prosecutors; fourth, the mechanism for granting compensation through the courts is long and often protracted, while the victim needs quick compensation treatment [13].

Both crucial issues related to the conditions of providing compensation for victims of gross violations of human rights and terrorism. Even so, the existence of the Witness and Victim Protection Act in 2014 signaled the continuing improvement made by the government on the model of providing compensation for victims of certain crimes in Indonesia. The law has renewed several contexts in the provision of compensation for victims of gross human rights violations and terrorism, some of which are the involvement of the Witness and Victim Protection Agency (LPSK) [3] as a decision-making institution to be submitted to the court for compensation for victims of crime. However, these developments do not necessarily remove the problems that come with the provision of compensation that has been rolled out before the Witness and Victim Protection Act, which continues to put forward the court process as a place for compensation [14-15].

\subsection{Reforming the Compensation Model to Victims of Crime in the Future}

Based on the review of the conditions of compensation given above, the need for an ideal idea of the model, form and mechanism for providing compensation to victims of crime in the future is the right step to overcome the compensation problem. In more detail, the analysis of the ideal idea can at least be seen as follows; First, the concept of providing compensation is carried out with a special institution that focuses on carrying out the function of providing compensation for victims of crime. If all this time the concept of providing compensation through the courts is considered to be less effective as previously explained, the existence of a special institution with the main duties and functions specifically handling the granting of compensation to victims of crime is the right solution. The institution is a representation of the state in fulfilling its obligations to the rights of victims of crime. The course of the practice of giving compensation through special institutions has indeed been applied in Indonesia, namely through Law No. 27 of 2004 which gives authority to special institutions in deciding to accept or reject compensation for victims of crime. The provision of compensation outside the court line has also been implemented by several developed countries such as the Netherlands with a special institution called the Damages Fund for Violent [16] and the United States through the Crime Victim Compensation Board [16] which shows that the provision of compensation through special institutions can be an alternative solution for the institution of compensation for victims of crime.

Second, the form of compensation that is given should not only be material, but also can be in the form of immaterial based on clear terms and indicators. The failure experienced in the Terrorism Act in implementing immaterial compensation forms is based on indicators about forms that are not clearly regulated in various existing regulations, so that the implementation of compensation with non-material forms has not yet been implemented. Adequate regulation with confirmation of compensation that can be material and immaterial is needed. Such as the United States involving hospital elements in the implementation of immaterial compensation forms in the form of medical consultations [16] is an illustration that immaterial compensation is needed.

Third, the mechanism for providing compensation must be based on the consideration of all elements involved in the cycle of crime. Just like the restorative justice theory put forward by Liebmann that the mechanism of compensation is likened to a legal system that aims to 
restore the welfare of victims, perpetrators, and society (the state) damaged by crime, and aimed at prevention so that no crime continues [17]. The restorative justice framework can be seen in the following figure:

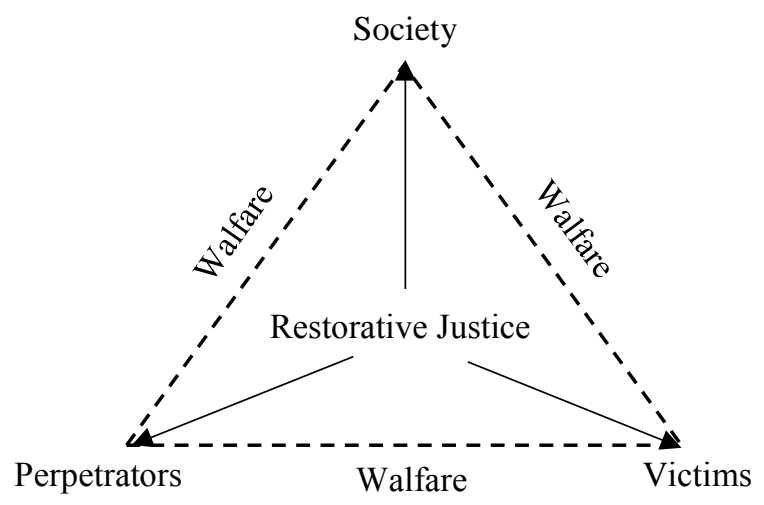

\section{Restorative Justice Concept}

This mechanism is very closely related to the aim of prospering the entire element in the event of crime, such as victims, perpetrators, and the community (the state) as well as in compensation. The principles contained in restorative justice are [17]: first, prioritizing victim support and healing; second, the perpetrators are responsible for what they do (criminal acts); third, dialogue between victims and perpetrators to achieve understanding; fourth, there are efforts to put in place the losses incurred; fifth, the perpetrator must be aware of how to avoid future crimes; and sixth, the society (the state) helps in integrating the two parties, both victims and perpetrators. Compensation for victims of crime through a restorative justice approach provides a platform for all parties to be considered and heard as a consideration in deciding cases of compensation. A mechanism that is deemed not to be obsolete by time, because of its nature to be able to keep up with the need for compensation with a broader objective, namely to provide guarantees for all parties involved to obtain compensation results that are in accordance with various perspectives [18].

\section{Conclusion}

The provision of compensation so far has not shown the effectiveness of fulfilling the rights of victims of crime both in concept, juridical and institutional practice for victims of gross human rights violations and terrorism. The ideal idea to overcome this problem is realized in several ways, namely; first, the provision of compensation through special institutions as a state representation in the fulfillment of compensation for victims of crime; second, the implementation of compensation in the form of material and non-material with clear and comprehensive arrangements; third, the compensation mechanism is carried out with a restorative justice approach to provide a participatory forum for victims, perpetrators and the society (the state) in deciding the provision of welfare-based compensation to the three elements at once. 


\section{References}

1. The 1945 Constitution of the Reppublic of Indonesia

2. S. Herman, M. Waul, Repairing the Harm: A New Vision for Crime Victims Compensation. (Nationl Center for Victims of Crime, Washington DC, 2004)

3. Law Number 31 of 2014 concerning Protection of Witnesses and Victims

4. D.A. Rachman, Komnas HAM Harap Jaminan Kompensasi Dipermudah. (Kompas, Jakarta, 14/05/2018)

5. A. Nursalikah, Korban Kejahatan Berhak Dapat Kompensasi dari Negara. (Republika, Jakarta, 31/03/2017)

6. Government Regulation Number 3 of 2002 concerning Compensation, Restitution and Rehabilitation Towards Victims of Human Rights Violations

7. I. Kasim, Mereka yang Menjadi Korban Hak Korban atas Restitusi, Kompensasi, dan Rehabilitasi. (ELSAM, Jakarta, 2002)

8. Y. Yulia, Saksi dan Korban: Antara Tanggung Jawab Hukum, Pemenuhan Hak dan Perlindungannya, 2, 110 (2012)

9. W. Wagiman, Z. Abidin, Praktik Kompensasi dan Restitusi di Indonesia: Sebuah Kajian Awal. (Indonesian Corruption Wacth, The Isntitute for Criminal Justice Reforme, Koalisi Perlindungan Saksi, Jakarta, 2007)

10.Z. Zulkifli, Kompensasi dan Restitusi Bagi Korban Pelanggaran Hak Asasi Manusia yang Berat. (Fakultas Hukum Universitas Indonesia, Jakarta, 2011)

11. S.W. Eddyono, Z. Abidin, Memastikan Pemenuhan Hak atas Reparasi Korban Pelanggaran HAM yang Berat. (Institute for Criminal Justice Reform, Jakarta, 2016)

12. , Academic Text of the Terrorism Act. (Supreme Court of the Republic of Indonesia, Jakarta, 2007)

13. S.W. Eddyono, Minimnya Hak Korban dalam RUU Pemberantasan Terorisme: Usulan Rekomendasi atas RUU Pemberantasan Terorisme di Indonesia. (Institute for Criminal Justice Reform, Jakarta, 2016)

14. Law Number 15 of 2003 concerning the Eradication of Acts of Terrorism

15. Law Number 26 of 2000 concerning Human Rights Courts

16. I.B.S.D. Jaya, I.G.K. Ariawan, I.M.W. Putra, I.G.A.A.D. Widhiyaastuti, I.B.M.D. Krisnawan, M.D. Pranajaya, Kompensasi sebagai Upaya Pelayan pada Korban Kejahatan Kekerasan. (Universitas Udayana, Bali, 2015)

17. M. Liebmann, Restorative Justice: How it Works. (Jessica Kingsley Publishers, London and Philadelphia, 2007)

18. L.M. Friedman, The Legal System: A Social Science Perspective. (Russel Sage Foundation, New York, 1969) 